\title{
Faktor-Faktor yang Berhubungan dengan Perilaku Hidup Bersih dan Sehat pada Pedagang Angkringan di Kawasan Malioboro Yogyakarta
}

\author{
Factors Associated with Clean and Healthy Life Behavior in Angkringan Traders in the Malioboro \\ Region of Yogyakarta
}

\section{Fardhiasih Dwi Astuti ${ }^{1}$, Dyah Suryani ${ }^{2}$}

\author{
${ }^{1,2}$ Program Studi Kesehatan Masyarakat, FKM Universitas Ahmad Dahlan, Yogyakarta \\ e-mail: ${ }^{1}$ fardhiasih.dwiastuti@ikm.uad.ac.id, ${ }^{2}$ dyah.suryani@ikm.uad.ac.id
}

\begin{abstract}
Abstrak
Kondisi sehat seseorang dapat dicapai dengan mengubah perilaku yang tidak sehat menjadi perilaku yang sehat dan menciptakan lingkungan yang sehat. Penerapan Perilaku Hidup Bersih dan Sehat (PHBS) di lingkungan tempat kerja merupakan salah satu upaya strategis untuk menggerakkan dan memberdayakan pekerja untuk berperilaku hidup bersih dan sehat. Angkringan adalah salah satu tempat makan tradisional yang ada di Indonesia. Oleh karena itu pedagang harus memiliki perilaku kebersihan dan kesehatan. Tujuan dari penelitian ini untuk mengetahui faktor-faktor yang berhubungan dengan perilaku hidup bersih dan sehat pada pedagang angkringan di Kawasan Malioboro Yogyakarta. Jenis penelitian ini merupakan penelitian observasional analitik dengan rancangan cross sectional. Sampel pada penelitian ini yaitu pedagang angkringan di Kawasan Malioboro Yogyakarta dengan jumlah 40 pedagang angkringan. teknik pengambilan sampel yang digunakan yaitu Total Sampling. Instrumen penelitian yang digunakan adalah kuesioner. Analisis data yang digunakan analisis univariat dan analisis bivariat dengan uji statistik Chi Square. Hasil uji statistik penelitian dengan menggunakan kuesioner kepada 40 pedagang angkringan, menunjukkan bahwa sebanyak 35 pedagang angkringan berjenis kelamin laki-laki yaitu $(87,5 \%)$, sebanyak 23 pedagang angkringan mayoritas kelompok lansia yaitu $(57,5 \%)$, sebanyak 21 pedagang angkringan $(52,5 \%)$ yang memiliki pendidikan rendah. Sebanyak 30 pedagang angkringan $(75,5 \%)$ yang berpengetahuan rendah, dan sebanyak 36 pedagang angkringan $(90,0 \%)$ yang memiliki sikap baik. Tidak ada hubungan antara pengetahuan ( $p=0,693)$, sikap $(p=1,000)$, umur $(p=0,301)$, dan jenis kelamin $(p=0,149)$ dengan Perilaku Hidup Bersih dan Sehat (PHBS). Ada hubungan antara pendidikan $(p=0,011)$ dengan Perilaku Hidup Bersih dan Sehat (PHBS).
\end{abstract}

Kata kunci: Pengetahuan, Sikap, karakteristik, Perilaku Hidup Bersih dan Sehat (PHBS)

\section{Abstract}

Healthy conditions can be achieved by changing unhealthy behavior into healthy behavior and creating a healthy environment. The application of PHBS in the workplace environment is one of the strategic efforts to mobilize and empower workers to behave in a clean and healthy life. Angkringan is one of feeding traditional place that owned by Indonesia. Hence, traders of Angkringan must have behavior cleanliness and health. The purpose of this study is to find out the factor releated to the behaviour of Clean and Healthy Life in Angkringan traders in Malioboro Region, Yogyakarta. This type of research was an observational analytic study with cross sectional. The sample in this study was the angkringan traders in Malioboro Region Yogyakarta with the number of 40 angkringan traders. The sampling technique that used was Total Sampling. The research instrument that used was a questionnaire. Data analysis that used univariate analysis and bivariate analysis with Chi Square statistical test. The results of statistical research tests using questionnaires to 40 angkringan traders, showed that as many as 35 angkringan traders were male, namely (87.5\%), as many as 23 angkringan traders, the majority were elderly groups (57.5\%), as many as 21 angkringan traders (52.5\%) who had low education. As many as 30 angkringan traders (75.5\%) had low knowledge, and as many as 36 angkringan traders (90.0\%) had a good attitude. There was not relationship between knowledge $(p=0,693)$, attitude $(p=1,000)$, age $(p=0,301)$, and sex $(p=0,149)$ with Clean and Healthy Life Behavior. There was a relationship between education $(p=0,011)$ with Clean and Healthy Life Behavior (PHBS).

Keywords: Knowledge, Attitude, Characteristics, Clean and Healthy Life Behavior (PHBS)

\section{Pendahuluan}

Menteri Kesehatan Republik Indonesia telah membuat Pedoman Pembinaan Perilaku Hidup Bersih dan Sehat yang tertuang dalam Peraturan Menteri Kesehatan Republik Indonesia Nomor 2269/MENKES/PER/XI/2011 yang didalamnya mengatur upaya peningkatan perilaku hidup bersih dan sehat atau disingkat PHBS di seluruh Indonesia dengan mengacu 
kepada pola manajemen PHBS, mulai dari tahap pengkajian, perencanaan, dan pelaksanaan serta pemantauan dan penilaian. Upaya tersebut dilakukan untuk memberdayakan masyarakat dalam memelihara, meningkatkan dan melindungi kesehatannya sehingga masyarakat sadar, mau, dan mampu secara mandiri ikut aktif dalam meningkatkan status kesehatannya ${ }^{1}$.

Perilaku Hidup Bersih dan Sehat (PHBS) adalah sekumpulan perilaku yang dipraktikkan atas dasar kesadaran sebagai hasil pembelajaran, yang menjadikan seseorang, keluarga, kelompok atau masyarakat mampu menolong dirinya sendiri (mandiri) di bidang kesehatan dan berperan aktif dalam mewujudkan kesehatan masyarakat. Perilaku hidup bersih dan sehat dapat diberlakukan di rumah tangga, tempat kerja, di sekolah, dan juga di tempat umum².

Pembinaan PHBS di tempat kerja dilakukan atas dasar Keputusan Menteri Kesehatan Nomor: 1114/MENKES/SK/2004 tentang pedoman pelaksanaan Promosi Kesehatan di daerah serta KEMENKES Nomor: 1405/MENKES/SK/2002 tentang persyaratan kesehatan lingkungan kerja perkantoran dan industri. Lingkungan tempat kerja yang sehat akan membuat karyawan atau pegawai merasa nyaman sehingga lebih produktif. Oleh karena itu kegiatan PHBS di tempat kerja harus dimulai dari unit terkecil yang ada di lingkungan tempat kerja ${ }^{3}$.

Ada beberapa faktor yang mempengaruhi penerapan Perilaku Hidup Bersih Sehat (PHBS) pada tatanan tempat kerja. Sesuai dengan teori Lawrence Green menjelaskan bahwa faktor perilaku ditentukan oleh tiga faktor utama yaitu faktor predisposisi (predisposing factors), yaitu faktor-faktor yang mempermudah atau mempredisposisi terjadinya perilaku seseorang atau masyarakat, antara lain pengetahuan dan sikap seseorang atau masyarakat terhadap apa yang akan dilakukan. Faktor-faktor pemungkin (enabling factors), merupakan faktor-faktor yang memungkinkan atau memfasilitasi perilaku seseorang atau masyarakat. Faktor faktor penguat (reinforcing factors), yaitu faktorfaktor yang memperkuat atau mendorong terjadinya perilaku ${ }^{4}$.

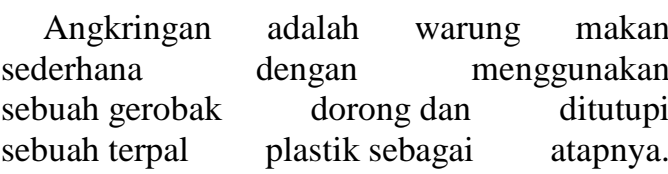
Keunikan dari Angkringan ini terletak pada gerobak dorongnya yang serba guna. Selain untuk memanaskan air atau memasak, gerobak Angkringan ini juga berfungsi sebagai tempat menaruh makanan dan sebagai meja makan para pembeli. Angkringan ini sangat terkenal di Yogyakarta, dan menjadi salah satu icon kuliner di Yogyakarta. Karena sebagai icon Yogyakarta maka pedagang Angkringan haruslah selalu berperilaku hidup bersih dan sehat agar makanan dan minuman yang disajikan aman dikonsumsi oleh konsumen. Berdasarkan survey pedahuluan pada pedagang angkringan di kawasan malioboro, ditemukan pedagang angkringan belum berperilaku hidup bersih dan sehat seperti masih belum menjaga kebersihan peralatan alat makan dan minum, mayoritas pedagang angkringan yang tidak menggunakan air mengalir tetapi hanya menggunakan ember untuk wadah air. Terkadang juga para pedagang ada yang merokok saat berjualan, selain itu makanan yang dijual tidak ditutup sehingga bisa terkena bakteri. Para pedagang angkringan juga pengetahuan dan bahkan sikapnya masih kurang tentang PHBS.

Tujuan penelitian ini adalah untuk mengetahui hubungan pengetahuan, sikap, umur, jenis kelamin, dan pendidikan dengan perilaku hidup bersih dan sehat di Kawasan Malioboro Yogyakarta. 


\section{Metode Penelitian}

Jenis penelitian ini merupakan penelitian kuantitatif dengan rancangan penelitian crosssectional. Variabel bebas dalam penelitian ini adalah pengetahuan, sikap, umur, jenis kelamin, dan pendidikan. Variabel terikat dalam penelitian ini adalah perilaku hidup bersih dan sehat. Jumlah populasi yang digunakan seluruh pedagang angkringan di kawasan Malioboro Yogyakarta dengan jumlah 40 pedagang angkringan. Sampel pada penelitian ini yaitu seluruh pedagang angkringan di kawasan Malioboro Yogyakarta. Teknik pengambilan sampel dalam penelitian ini menggunakan totality sampling. Pengumpulan data dilakukan dengan menggunakan kuesioner. Analisis data menggunakan uji statistik chi square dengan uji alternatif fisher exact test dengan Confidence Interval $95 \%$ dan tingkat kemaknaan $p$ value 0,05 .

\section{Hasil}

\section{Analisis Univariat}

Berdasarkan hasil penelitian distribusi subjek penelitian menurut karakteristik jenis kelamin, umur, pendidikan, pengetahuan, sikap dan perilaku hidup bersih dan sehat dapat dilihat dalam tabel 1 sebagai berikut:
Tabel 1. Distribusi Responden Penelitian

\begin{tabular}{llcc}
\hline \multirow{2}{*}{ Karakteristik } & Kategori & $\begin{array}{c}\text { Frekuensi } \\
(\mathrm{n})\end{array}$ & $\begin{array}{c}\text { Persentase } \\
(\%)\end{array}$ \\
\hline Jenis & Laki-laki & 35 & 87.5 \\
Kelamin & Perempuan & 5 & 12.5 \\
\multirow{2}{*}{ Umur } & Lansia & 23 & 57,5 \\
\multirow{4}{*}{ Pendidikan } & Dewasa & 17 & 42,5 \\
\multirow{3}{*}{ Pengetahuan } & Rendah & 21 & 52,5 \\
& Tinggi & 19 & 47,5 \\
\multirow{3}{*}{ Sikap } & Rendah & 30 & 75.0 \\
& Tinggi & 10 & 25.0 \\
\multirow{2}{*}{ PHBS } & Buruk & 4 & 10.0 \\
& Baik & 36 & 90.0 \\
& Rendah & 12 & 30.0 \\
& Tinggi & 28 & 70.0 \\
\hline
\end{tabular}

Berdasarkan Tabel 1, diketahui bahwa dari total 40 responden didapatkan hasil deskripsi mengenai jenis kelamin mayoritas responden berjenis kelamin laki-laki sebanyak 35 responden $(87.5 \%)$, mayoritas umur lansia sebanyak 23 responden $(57.5 \%)$, memiliki mpendidikan rendah sebanyak 21 responden (52.5\%), memiliki pengetahuan rendah sebanyak 30 responden (75.0\%), sikap baik sebanyak 36 responden (90.0), PHBS responden kategori tinggi sebanyak 28 $(70.0 \%)$.

\section{Analisis Bivariat}

Berdasarkan hasil penelitian hubungan jenis pengetahuan sikap, kelamin, umur, pendidikan, dengan perilaku hidup bersih dan sehat (PHBS) dapat dilihat dalam tabel 2

Tabel 2. Hasil Uji Hubungan Variabel Bebas dan Terikat

\begin{tabular}{|c|c|c|c|c|c|c|c|c|c|}
\hline \multirow{3}{*}{ Variabel } & \multicolumn{6}{|c|}{ Perilaku Hidup Bersih Dan Sehat } & \multirow{3}{*}{$\mathrm{RP}$} & \multirow{3}{*}{$\begin{array}{c}\text { CI } \\
(95 \%)\end{array}$} & \multirow{3}{*}{$P$ value } \\
\hline & \multicolumn{2}{|c|}{ Rendah } & \multicolumn{2}{|c|}{ Tinggi } & \multicolumn{2}{|c|}{ Total } & & & \\
\hline & $\mathrm{n}$ & $\%$ & $\mathrm{n}$ & $\%$ & $\mathrm{n}$ & $\%$ & & & \\
\hline \multicolumn{10}{|l|}{ 1. Pengetahuan } \\
\hline Rendah & 10 & 25,0 & 20 & 50,0 & 30 & 75,0 & \multirow{3}{*}{1,667} & & \multirow{3}{*}{0,693} \\
\hline Tinggi & 2 & 5,0 & 8 & 20,0 & 10 & 25,0 & & & \\
\hline Jumlah & 12 & 30,0 & 28 & $\mathbf{7 0 , 0}$ & 40 & 100 & & & \\
\hline \multicolumn{10}{|l|}{ 2. Sikap } \\
\hline Buruk & 1 & 2,5 & 3 & 7,5 & 4 & 10,0 & \multirow{3}{*}{0,818} & & \multirow{3}{*}{1,000} \\
\hline Baik & 11 & 27,5 & 25 & 62,5 & 36 & 90,0 & & & \\
\hline Jumlah & 12 & 30,0 & 28 & $\mathbf{7 0 , 0}$ & 40 & 100 & & & \\
\hline
\end{tabular}




\begin{tabular}{|c|c|c|c|c|c|c|c|c|c|}
\hline \multirow{3}{*}{ Variabel } & \multicolumn{6}{|c|}{ Perilaku Hidup Bersih Dan Sehat } & \multirow{3}{*}{$\mathrm{RP}$} & \multirow{3}{*}{$\begin{array}{c}\text { CI } \\
(95 \%)\end{array}$} & \multirow{3}{*}{$P$ value } \\
\hline & \multicolumn{2}{|c|}{ Rendah } & \multicolumn{2}{|c|}{ Tinggi } & \multicolumn{2}{|c|}{ Total } & & & \\
\hline & $\mathrm{n}$ & $\%$ & $\mathrm{n}$ & $\%$ & $\mathrm{n}$ & $\%$ & & & \\
\hline \multicolumn{10}{|l|}{ 3. Umur } \\
\hline Lansia & 4 & 10,0 & 16 & 40,0 & 20 & 50,0 & \multirow{3}{*}{0,500} & & \multirow{3}{*}{0,301} \\
\hline Dewasa & 8 & 20,0 & 12 & 30,0 & 20 & 50,0 & & & \\
\hline Jumlah & 12 & 30,0 & 28 & $\mathbf{7 0 , 0}$ & 40 & 100 & & & \\
\hline \multicolumn{10}{|l|}{ 4. Jenis Kelamin } \\
\hline Laki-laki & 9 & 22,5 & 26 & 65,0 & 35 & 87,5 & \multirow{3}{*}{0,429} & & \multirow{3}{*}{0,149} \\
\hline Perempuan & 3 & 7,5 & 2 & 5,0 & 5 & 12,5 & & & \\
\hline Jumlah & 12 & 30,0 & 28 & $\mathbf{7 0 , 0}$ & 40 & 100 & & & \\
\hline \multicolumn{10}{|l|}{ 5. Pendidikan } \\
\hline Rendah & 10 & 25,0 & 11 & 27,5 & 21 & 52,5 & \multirow{3}{*}{4,524} & 1,132- & \multirow{3}{*}{0,011} \\
\hline Tinggi & 2 & 5,0 & 17 & 42,5 & 19 & 47,5 & & 18,082 & \\
\hline Jumlah & 12 & 30,0 & 28 & 70,0 & 40 & 100 & & & \\
\hline
\end{tabular}

Berdasarkan tabel 2, hasil analisis faktorfaktor yang berhubungan dengan perilaku hidup bersih dan sehat pada pedagang angkringan di kawasan Malioboro Yogyakarta. Hasil analisis hubungan antara pengetahuan dengan perilaku hidup bersih dan sehat didapatkan nilai $p$ value $0,693>\alpha 0,05$ yang artinya tidak ada hubungan antara pengetahuan dengan perilaku hidup bersih dan sehat. Sedangkan hasil analisis hubungan antara Sikap dengan Perilaku Hidup Bersih dan Sehat (PHBS) didapat nilai $p$ value 1,000> $\alpha 0,05$ yang artinya tidak ada hubungan antara pengetahuan dengan perilaku hidup bersih dan sehat.

Analisis hubungan Umur dengan Perilaku Hidup Bersih dan Sehat (PHBS), didapat nilai $p$ value $0,301>\alpha 0,05$ yang artinya tidak ada hubungan antara umur dengan perilaku hidup bersih dan sehat. Untuk hasil analisis hubungan jenis kelamin dengan Perilaku Hidup Bersih dan Sehat (PHBS), mempunyai nilai $p$ value $0,149>\alpha 0,05$ yang artinya tidak ada hubungan antara umur dengan perilaku hidup bersih dan sehat. Dan hasil analisis hubungan pendidikan dengan Perilaku Hidup Bersih dan Sehat (PHBS), terdapat nilai $p$ value $0,011<\alpha \quad 0,05$ yang artinya ada hubungan antara pendidikan dengan perilaku hidup bersih dan sehat. Nilai RP 4,524>1 Confident Interval (CI) 0.787-1.746 yang berarti bahwa pendidikan yang rendah menyebabkan kesadaran untuk berperilaku hidup bersih dan sehat yang tidak baik sebesar 4,524 kali lebih besar dibandingkan dengan yang berpendidikan tinggi.

\section{Pembahasan}

\section{Hubungan Pengetahuan dengan Perilaku Hidup Bersih dan Sehat (PHBS)}

Berdasarkan hasil uji analisis bivariat menggunakan uji Fisher diperoleh $P$ value $0,693>\alpha 0,05$, maka dapat diketahui bahwa tidak ada hubungan antara pengetahuan dengan perilaku hidup bersih dan sehat pada pedagang angkringan di kawasan Malioboro. Walaupun tidak ada hubungan antara pengetahuan dengan perilaku hidup bersih dan sehat pada pedagang angkringan di kawasan Malioboro, tetapi pengetahuan memiliki faktor resiko terhadap perilaku hidup bersih dan sehat. Masih banyak pengetahuan yang rendah dalam penelitian ini. Kemungkinan dikarenakan tingkat pendidikan yang rendah. Faktor-faktor yang mempengaruhi pengetahuan yaitu pendidikan, usia, pengalaman, lingkungan dan budaya. Pengetahuan seseorang dapat diperoleh secara internal maupun eksternal. Pengetahuan secara internal yaitu pengetahuan yang berasal dari 
dirinya sendiri berdasarkan pengalaman hidup. Sedangkan pengetahuan eksternal yaitu pengetahuan yang diperoleh dari orang lain yang dianggap penting 5 . Pengetahuan yang didapat dari internal maupun eksternal dapat menambah pengetahuan pedagang angkringan sehingga berperilaku hidup bersih dan sehat. Perilaku yang didasarkan pada pengetahuan akan lebih banyak abadi daripada dalam perilaku yang mendasari oleh pengetahuan. Kemudian muncul persepsi individu dan yang munculsikap, niat, keyakinan/keyakinan dapat memotivasi dan mewujudkan keinginan untuk menjadi suatu tindakan.

Hasil penelitian ini sejalan dengan penelitian terdahulu yang menunjukkan bahwa tidak ada hubungan antara pengetahuan dengan perilaku hidup bersih dan sehat pada pekerja bagian produksi PT. Coca Cola Amatil Indonesia $^{6}$. Tapi penelitian ini berbanding terbalik pada ibu rumah tangga di Kecamatan Cimahi Utara yang menunjukkan bahwa ada hubungan yang signifikan antara pengetahuan dan penerapan perilaku hidup bersih dan sehat dalam tatanan rumah tangga ${ }^{7}$.

\section{Hubungan Sikap dengan Perilaku Hidup Bersih dan Sehat (PHBS)}

Berdasarkan hasil uji analisis bivariat menggunakan uji Fisher diperoleh $P$ value $1,000>\alpha 0,05$, maka dapat diketahui bahwa tidak ada hubungan antara sikap dengan perilaku hidup bersih dan sehat pada pedagang angkringan di kawasan Malioboro. Masih ada pedagang yang sikapnya buruk dan berperilaku tidak baik. Hal ini bisa terjadi karena masih kurangnya kesadaran dan pemahaman tentang perilaku hidup bersih dan sehat sehingga reaksi pedagang masih kurang. Dan ada beberapa faktor lain yang tidak mendukung perilaku hidup bersih dan sehat maka menyebabkan tidak terlaksananya indikator perilaku hidup bersih dan sehat dengan baik. Walaupun sikap pedagang positif tetapi apabila sarana dan prasarananya tidak tersedia maka akan berpengaruh terhapa pelaksanan perilaku hidup bersih dan sehat.

Penelitian terdahulu menyatakan bahwa infrastruktur dalam hal ini adalah kondisi serta kelengkapannya, peralatan dan fasilitas akan mendukung promosi kesehatan yang mempengaruhi individu dalam pelaksanaan perilaku hidup bersih dan sehat ${ }^{8}$.

Hasil penelitian ini sejalan dengan terdahulu yang menunjukkan bahwa tidak ada hubungan antara sikap dengan perilaku hidup bersih dan sehat pada pekerja bagian produksi PT. Coca Cola Amatil Indonesia ${ }^{6}$. Namun tidak sejalan dengan penelitian terdahulu yang menyatakan bahwa ada hubungan antara sikap dengan perilaku hidup bersih dan sehat di Wilayah Kerja Puskesmas Sombaopu Gowa ${ }^{9}$.

\section{Hubungan Umur dengan Perilaku Hidup Bersih dan Sehat (PHBS)}

Berdasarkan hasil uji analisis bivariat menggunakan uji Chi square diperoleh $P$ value $0,301>\alpha 0,05$, maka dapat diketahui bahwa tidak ada hubungan antara umur dengan perilaku hidup bersih dan sehat pada pedagang angkringan di kawasan Malioboro. Semakin cukup umur tingkat kematangan seseorang akan lebih matang dalam berfikir dan bekerja. Dari segi kepercayaan masyarakat, seseorang yang lebih dewasa lebih dipercayai dari pada orang yang belum tinggi tingkat kedewasaannya. Hal ini dilihat dari segi pengalaman dan kematangan jiwanya ${ }^{10}$.

Kesadaran akan risiko kesehatan cenderung kurang dengan kelompok usia yang lebih muda. Responden yang lebih muda unggul dalam aktivitas fisik dan domain keterlibatan sosial yang tidak terkait langsung dengan kesehatan, tetapi membutuhkan lebih banyak motivasi yang mungkin belum dimiliki responden usia yang lebih tua ${ }^{11}$. Penelitian ini sejalan dengan penelitian terdahulu yang tidak melaporkan adanya perbedaan yang signifikan 
perilaku hidup bersih dan sehat berdasarkan usia dalam penelitian yang dilakukan di Nigeria, sedangkan beberapa laporan sebelumnya menunjukkan bahwa orang tua cenderung menunjukkan perilaku kesehatan yang lebih baik ${ }^{12}$.

\section{Hubungan Jenis Kelamin dengan Perilaku Hidup Bersih dan Sehat (PHBS)}

Pada penelitian ini hasil uji Fisher didapatkan $\mathrm{p}=0,149$ dengan $\alpha=0,05$ yang berarti tidak ada hubungan antara jenis kelamin dengan perilaku hidup bersih dan sehat. Jenis kelamin merupkan faktor predisposing atau faktor pemudah seseorang untuk berperilaku. Namun pada penelitian ini hasilnya berbeda yaitu tidak ada hubungan antara jenis kelamin dengan perilaku hidup bersih dan sehat. Hal ini disebabkan karena untuk membentuk perilaku banyak sekali faktor pendukungnya, tidak hanya jenis kelamin tetapi banyak faktor lainnya ${ }^{13}$. Hal ini dikarenakan jenis kelamin laki-laki dan perempuan mempunyai kesempatan yang sama untuk melakukan atau tidak melakukan perilaku hidup bersih dan sehat.

Penelitian ini sejalan dengan penelitian terdahulu yang menyatakan bahwa tidak ada hubungan antara jenis kelamin dengan perilaku hidup bersih dan sehat sebagai upaya untuk pencegahan penyakit diare pada Siswa Di SD N Karangtowo Kecamatan Karangtengah Kabupaten Demak ${ }^{14}$. Namun penelitian ini tidak sejalan dengan penelitian terdahulu yang menyatakan ada hubungan antara jenis kelamin dengan perilaku hidup bersih dan sehat pada Siswa SD Negeri 25 Begori Kecamatan Serawai Kabupaten Sintang ${ }^{15}$.

\section{Hubungan Pendidikan dengan Perilaku Hidup Bersih dan Sehat (PHBS)}

Berdasarkan hasil uji analisis bivariat menggunakan uji Chi square di peroleh $P$ value $0,012<\alpha 0,05$, maka dapat diketahui bahwa ada hubungan antara pendidikan dengan perilaku hidup bersih dan sehat pada pedagang angkringan di kawasan Malioboro. Dan hasil statistik dengan $\alpha=0,05$ didapatkan nilai Ratio Prevalensi $(P R)=4.524$ dengan Confident Interval (CI) 1,132-18,082, yang berarti bahwa pedagang yang memiliki pendidikan rendah beresiko 4,524 kali lebih besar memiliki PHBS yang buruk dibandingkan pedagang yang memiliki pendidikan tinggi. Pendidikan rendah menunjukkan pengaruh terhadap perilaku hidup bersih dan sehat (PHBS). Pendidikan pedagang angkringan sangat berpengaruh terhadap perubahan sikap menuju perilaku hidup bersih dan sehat. Pendidikan yang rendah akan mempengaruhi pedagang angkringan dalam memperoleh dan mencerna informasi untuk kemudian menentukan pilihan dalam menerapkan perilaku hidup bersih dan sehat.

Pendidikan merupakan salah satu usaha pengorganisasian masyarakat untuk meningkatkan kesehatan karena tingkat pendidikan dapat mempengaruhi perilaku sehat keluarga dengan tingkat pendidikan yang kurang mendukung akan menyebabkan rendahnya kesadaran lingkungan, semakin baik tingkat pendidikan formal sehingga akan mematangkan pemahaman tentang pengetahuan kesehatan lingkungan dan kesadaran menjaga kesehatan lingkungan termasuk penerapan prinsip - prinsip $\mathrm{PHBS}^{6}$.

Hal ini sesuai dengan penelitian terdahulu yang menyatakan bahwa ada hubungan antara pendidikan dengan perilaku hidup bersih dan sehat pada pedagang makanan di kawasan Universitas Pakuan ${ }^{16}$. Namun tidak sejalan dengan penelitian terdahulu yang menyatakan tidak ada hubungan antara pendidikan dengan perilaku hidup bersih dan sehat pada 
Masyarakat Desa Pekonmon Kecamatan Ngambur Kabupaten Pesisir Barat ${ }^{17}$.

\section{Kesimpulan}

Berdasarkan hasil penelitian yang dilakukan mengenai Faktor-faktor yang berhubungan dengan perilaku hidup bersih dan sehat pada pedagang angkringan di Kawasan Malioboro Yogyakarta diperoleh kesimpulan sebagai berikut:

1. Tidak ada hubungan antara pengetahuan dengan perilaku hidup bersih dan sehat pada pedagang angkringan di kawasan Malioboro Yogyakarta.

2. Tidak ada hubungan antara sikap dengan perilaku hidup bersih dan sehat pada pedagang angkringan di kawasan Malioboro Yogyakarta.

3. Tidak ada hubungan antara umur dengan perilaku hidup bersih dan sehat pada pedagang angkringan di kawasan Malioboro Yogyakarta.

4. Tidak ada hubungan antara jenis kelamin dengan perilaku hidup bersih dan sehat pada pedagang angkringan di kawasan Malioboro Yogyakarta.

5. Ada hubungan anatar pendidikan dengan perilaku hidup bersih dan sehat pada pedagang angkringan di kawasan Malioboro Yogyakarta.

\section{Saran}

Perlu ditingkatkan upaya penyuluhan kesehatan khususnya di tempat kerja sehingga pedagang angkringan mengetahui arti pentingnya menciptakan dan menjaga kesehatan lingkungan di tempat kerja.

\section{Daftar Pustaka}

1. Depkes RI. 2010.Perilaku Hidup Bersih dan Sehat di Rumah Tangga. Jakarta: Departemen kesehatan

2. Kemenkes Republik Indonesia. 2011. Pedoman Pembinaan Perilaku Hidup
Bersih dan Sehat (PHBS). Kementerian Kesehatan RI. Jakarta

3. Maryunani, A. 2013. Perilaku Hidup Bersih dan Sehat (PHBS). Trans Info Media: Jakarta. Hal. 6, 24-25,189

4. Notoatmodjo, S. 2010. Promosi Kesehatan : Teori dan Aplikasi. Jakarta: Rineka Cipta. Hal. 4, 27-28

5. Sunaryo, 2004, Psikologi Keperawatan. Jakarta: EGC.

6. Restiyani, A., Cahyo, K., Widagdo, L., 2017. Faktor - Faktor Yang Berhubungan dengan Perilaku Hidup Bersih dan Sehat Pada Pekerja Bagian Produksi PT. Coca Cola Amatil Indonesia Centraljava. Jurnal Kesehatan Masyarakat. Vol. 5, No. 5 Oktober 2017. Hal. 2356-3346.

7. Budiman, Djamhuri DS, Juhaeriah, 2012. "Perilaku Hidup Bersih dan Sehat (Clean And Healthy Living Behaviour) Tatanan Rumah Tangga di Kelurahan Utama Kecamatan Cimahi Selatan Kota Cimahi”, Sains, Teknologi dan Kesehatan, ISSN 2089-3582.

8. Hati S, 2008. "Pengaruh Strategi Promosi Kesehatan Terhadap Tingkat Perilaku Hidup Bersih Dan Sehat (Clean And Healthy Living Behaviour) Pada Tatanan Rumah Tangga Di Kecamatan Patumbak Kabupaten Deli Serdang”. Thesis, Sekolah Pascasarjana Universitas Sumatera Utara, Medan.

9. Saini, S., dan Sukma, A., 2018. Pengetahuan dan Sikap Keluarga dalam Pelaksanaan Perilaku Hidup Bersih dan Sehat di Wilayah Kerja Puskesmas Sombaopu Gowa. Jurnal Media Keperawatan. Vol. 9, No. 1, Hal. 2622

10. Hurlock, E. 1998. Perkembangan Anak. Jakarta. Erlangga. Hal. 78-79

11. Ejechi, E.O., 2016. Assessment of Health Promotion Life Style of a Sample of Nigerians in Early Old Age. International Journal of Humanities and Social Science. Vol. 6, No. 5. pp.172-180. 
12. Olasunbo, O. I., Ayo, D. S.2013. Health seeking behaviour, food habit and nutritional assessment of an elderly group in Ile Ife, Nigeria. Journal of Community Medicine \& Health Education, 3(5): 1-5.

13. Notoatmodjo, S. 2007. Promosi Kesehatan dan Ilmu Perilaku. Jakarta: Rineka Cipta

14. Sari, N. I., Wijdarnako, B., dan Kusumawati, A. 2016. Faktor-Faktor Yang Berhubungan Dengan Perilaku Hidup Bersih dan Sehat Sebagai Upaya Untuk Pencegahan Penyakit Diare Pada Siswa Di Sd N Karangtowo Kecamatan Karangtengah Kabupaten Demak. Jurnal Kesehatan Masyarakat. Vol. 4, No.3, Hal. 1051-1058

15. Kruweh, N., H. 2016. Hubungan Jenis Kelamin, Pengetahuan, Sikap dan Peran Guru Dengan Perilaku Hidup Bersih dan Sehat Pada Siswa SD Negeri 25 Begori Kecamatan Serawai Kabupaten Sintang. Jurnal Wawasan Kesehatan. Vol. 2, No. 2, Hal. 61-75

16. Istiana, R., dan Awaludin, M, T. 2017. Perilaku Hidup Bersih Dan Sehat Peda pedagang Makanan Di Kawasan Universitas Pakuan. Jurnal Ilmiah pendidikan. Vol. 1, No. 1, Hal. 15-25

17. Adliyani, O. Z., Anggraini, I. D., dan Soleha, U., T. 2017. Pengaruh Pengetahuan, Pendidikan dan Ekonomi Terhadap Perilaku Hidup Bersih dan Sehat pada Masyarakat Desa Pekonmon Kecamatan Ngambur Kabupaten Pesisir Barat. Jurnal Majority. Vol. 7, No. 2, Hal. 6-13 